\title{
Application of the Bayes Theorem to the Expert System for Diagnosing Big Red Chili Plants
}

\author{
Esa Firmansyah ${ }^{1}$, Cecep Hidayat $^{2}$, Ripa Maulida Husna ${ }^{3}$, Sy. Yuliani ${ }^{4}$, Rio Guntur Utomo ${ }^{5}$ \\ esa@stmik-sumedang.ac.id, cecephidayat@uinsgd.ac.id, ripa@if.uinsgd.ac.id, \\ yuliani@widyatama.ac.id, rioguntur@soton.ac.uk \\ Department of Informatics, STMIK Sumedang, Indonesia ${ }^{1}$ \\ Department of Informatics, UIN Sunan Gunung Djati Bandung, Indonesia ${ }^{2-3}$, \\ Department of Informatics, Widyatama University Bandung, Indonesia ${ }^{4}$ \\ Department of Information Technology, University of Southampton, England ${ }^{5}$
}

\begin{abstract}
Big red chili is one of the plants that are easily affected by disease than curly and type of chili pepper, and easily contagious if unknown symptoms initially. The limited knowledge of the farmers or society that cultivate big red chili and lack of power extension officers make slow the process of diagnosis and can be fatal as death, so this is serious because it can be losses for the farmers or society that cultivate large red chili plants. To resolve the above problem researchers will conduct research based on the problem. Bayes theorem is one of the methods used to calculate the uncertainty of data into data that is sure to compare data between Yes and no. In this case, the value used to calculate the probability of outcomes identified in large red chili plant diseases. On the results of the experimental data of the symptoms of the disease generates value accuracy of $100 \%$.
\end{abstract}

Keywords: Large Red Chilli, Expert System, Bayes Theorem

\section{Introduction}

In this era of globalization, computers are one of the most important parts of human life, and have even become a necessity that is difficult for people to leave behind. Technological developments are increasingly rapidly making a lot of technology that can change the way human thinking is fixed in artificial intelligence. Artificial intelligence referred to in this discussion is an expert system. An expert system is a computer system that resembles the knowledge or experience of one or many experts who are transformed into certain knowledge to help the community in solving a specific problem in this case regarding the problem of diseases that occur in large red chili plants.

The agronomic characteristics of large red chili are flat or smooth, rather fat, thick fruit skin, early maturity, less resistant and not too spicy. Big red chili is a horticultural commodity that is classified as an annual crop, this plant is estimated to have around 20 species and most of these plants grow in their original place, namely America [1]. Big red chili is a plant that is susceptible to disease attacks, compared to curly or other chili. Big red chili is one of the plants 
that has many types of diseases and is easily transmitted to other plants if the initial symptoms are not known.

In the Lampung region and the responsiveness of the intensity of red pepper plants is $27 \%$ $-30 \%$ [2]. According to the central body of the Lampung statistics (2014) chili production during 2011-2013 tended to decline. One of the causes of decreased production is chili plant disease [3]. According to the horticulture research body In addition to the low agronomic factors, chili production is also caused by the presence of pests and diseases [4]. Some of the disease-causing fungi in chili plants are Gloesporium piperatum and Colletotrichum capsici which cause anthracnose or fruit rot, Cercospora capsici causes leaf spots and Cucumber Mosaic Virus (CMV) disease [5].

Farmers or communities that cultivate large red chili plants to date diagnose diseases still use manual methods, namely by observing the symptoms experienced by large red chili plants directly so that this takes a short time because there are many types of large chilli plants. . limited knowledge of farmers or communities that cultivate large red chilies And the lack of extension workers makes the diagnosis process late and can have fatal consequences such as death, so this becomes serious because it can be a disadvantage for farmers or communities who cultivate large red chili plants.

To solve the above problems researchers will conduct research based on existing problems. The purpose of this study is to design an expert system for diagnosing large red chili plants using the Bayes Theorem method, taking into account the symptoms experienced by large red chili plants. The diseases to be discussed consist of 10 types, namely: late blight (phytophthora), leaf spot (Cercospora), anthracnose rot, powdery mildew (powdery mildew), bacterial wilt (Pseudomonas), sprout drop, complex virus, Gemini yellow virus, Swollen root nematodes.

Bayes theorem is one method used to calculate the uncertainty of data into definite data by comparing data between yes and no [6]. In this case it is used to calculate the probability value of the results identified by the disease of large red chili plants. Based on the explanation above, the problems raised as the theme of the final assignment are entitled "Application of the Bayes Theorem to the Expert System for Diagnosing Large Red Chili Plants".

\section{Literature Review}

\subsection{Artificial Intelligence}

Artificial intelligence comes from English "Artificial Intelligence" or short AI, namely intelligence is an adjective that means intelligent, while artificial means artificial. Artificial learning in question refers Cto a machine that is capable of thinking, weighing actions to be taken and being able to make decisions as done by humans[7].

\subsection{Expert System}

An expert system is a branch of artificial intelligence and a field of science that has emerged along with the development of computer science today. This system is a computer system that can mimic the ability of an expert, this system works to adopt computer knowledge that combines basic computer knowledge (knowladge base) with an inference system to draw conclusions from a set of rules (rules)[8]. 


\subsection{Teorema Bayes}

Bayes theorem is one method used to calculate the uncertainty of data into definite data by comparing data between yes and no. Bayes probability is one way to overcome data uncertainty by using the stated Bayes Formula :

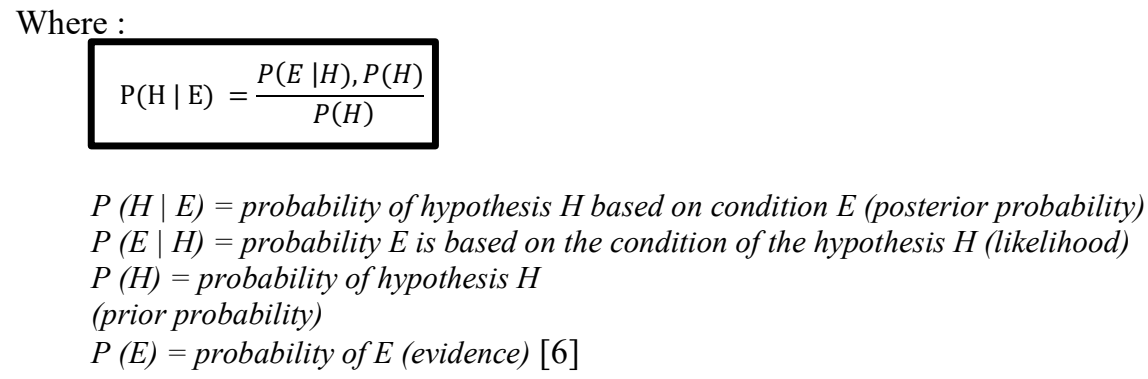

\subsection{Large Red Chili}

The agronomic characteristics of large red chili are flat or smooth, rather fat, thick fruit skin, early maturity, less resistant and not too spicy. Big red chili is a horticultural commodity that is classified as an annual crop, this plant is estimated to have around 20 species and most of these plants grow in their original place, namely America [1] .

\subsection{Plant Disease}

Some of the disease-causing fungi in chili plants are Gloeosporium piperatum and Colletotrichum capsici which cause anthracnose or rotten fruit, Cercospora capsici which causes leaf spots and cucumber mosaic virus (CMV) [5].

\subsection{Codeigniter (CI)}

CodeIgniter (CI) is a website development framework using PHP, a framework for working or creating programs using systematic PHP. CI provides a set of libraries needed in developing a website [9].

\section{Research Methods}

\subsection{Data Collection}

Data collection techniques by conducting research and direct review of the problems taken. in this case the interviewee was Yusuf Hidayat, SP, MPhil, PhD as a lecturer at the UNPAD faculty of agriculture from the Department of Plant Pest, Dr. Sri Hartati, SP., M.SI as a lecturer at the Faculty of Agriculture UNPAD from the Department of Plant Disease, Ir Tonny Koestoni Moekasan as the principal researcher of the Vegetable Crop Research Institute (BALITSA) Lembang.

\subsection{System Development}

Making this system is to use a prototype methodology. Stages in the prototyping method are according to the stages below : 


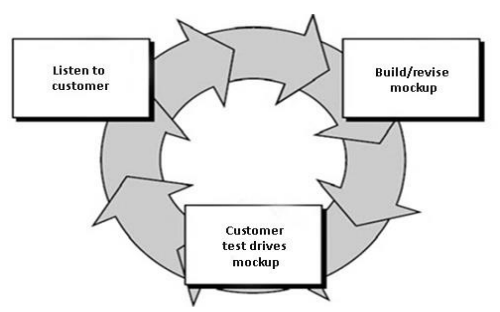

Fig. 1. Metode Prototype [10]

Stages in the prototyping method are according to the stages below:

\section{Listen to customer}

In this step carried out by interviewing several speakers to get the data needed to develop a software to diagnose the disease of large red chili plants. After the data is collected, system design and design are carried out as the initial image for the user visually.

2. Build mockup/revise mockup

in the next step make database design, coding and display design applied in expert system applications that aim to diagnose the disease of large red chili plants by applying the Bayes theorem method. The next step will be an evaluation of the application that will be made to avoid the risk of failure in the application.

3. Customertest drives mockup

In this step, evaluating and testing the expert system application to diagnose the disease by applying the Bayes theorem method, testing the application is done by resource persons and developers to ensure the effectiveness of the application built [10].

\section{Result \& Discussion}

\subsection{Flowchart}

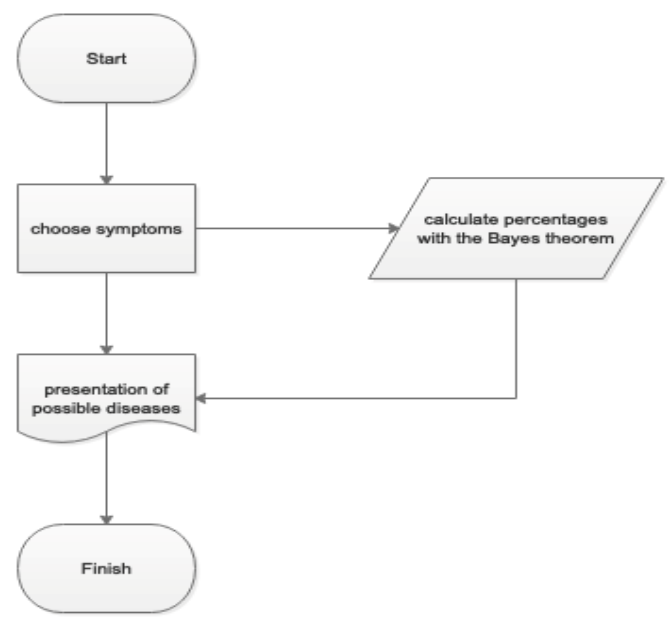

Fig. 2. Flowchart 
Generally the application to diagnose the disease by applying the Bayes theorem is explained by the flow cart besides.Figure 2 explains the system to find out the percentage of large red pepper disease, where first the user selects the symptoms experienced after that the system calculates the percentage of the probability of a large red chili plant disease using the Bayes Theorem method based on the selected symptoms. Then after that the user can find out the percentage of possible diseases of a large red chili plant.

\subsection{Usecase Diagram}

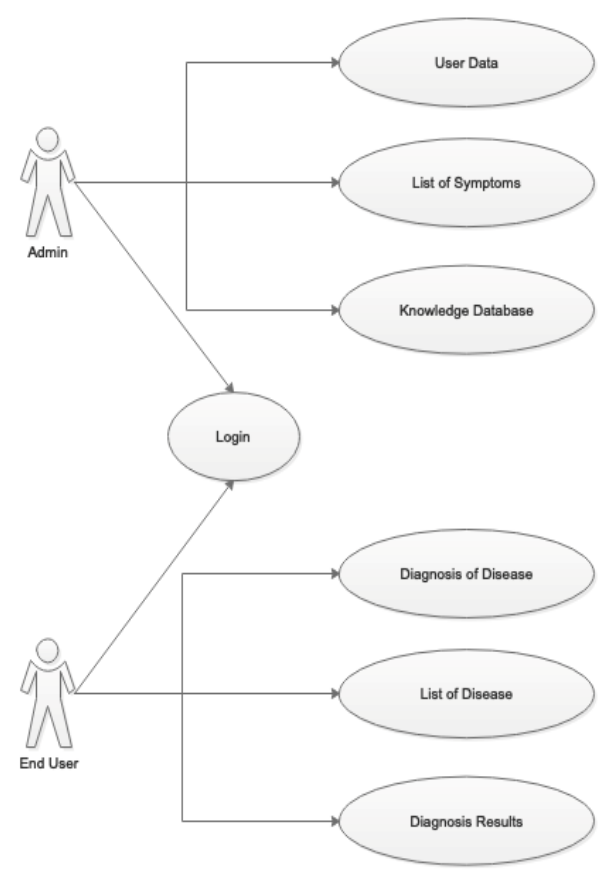

Fig. 3. Usecase Diagram

Figure 3. explain the relationship between the user and the system in the expert system application for diagnosing large red chili plants. Users can diagnose the disease and see a list of diseases that the system has provided. Admin can manage user data, manage disease data, manage symptom data and manage list of symptoms. Relationship between admin and user in expert system application for diagnosing large red chili plants, admin and user can login. 


\subsection{ACTIVITY DIAGRAM}

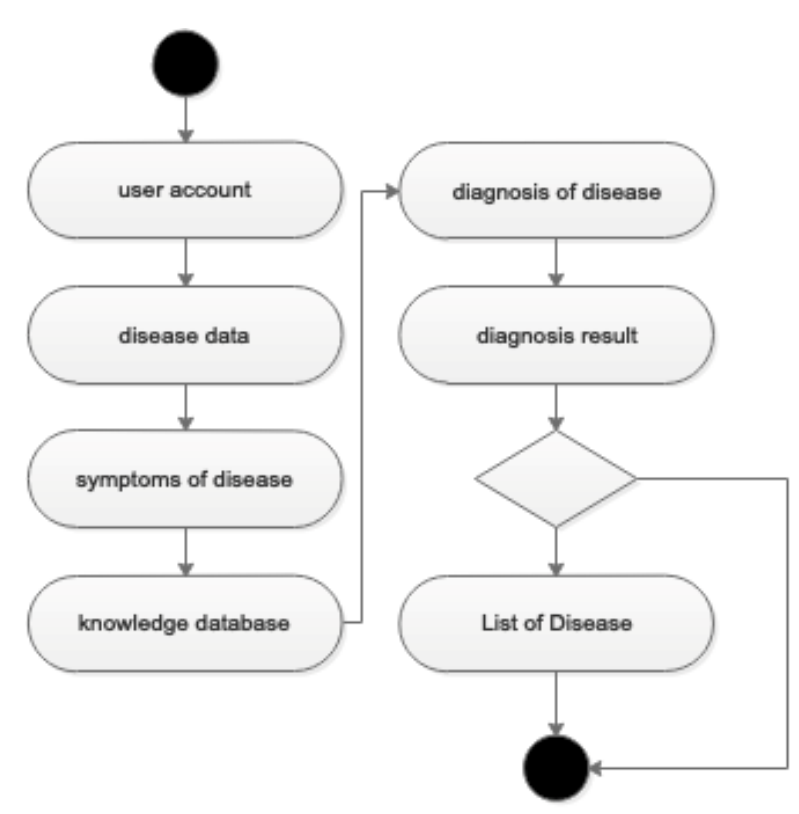

Fig. 4. Activity Diagram

In the picture depicting the activities that occur the admin can add user data, add disease data, add disease symptom data, add knowledge base data. the user diagnoses, then receives the diagnosis if it is correct the system will display the diagnosis.

\section{Squence Diagram}

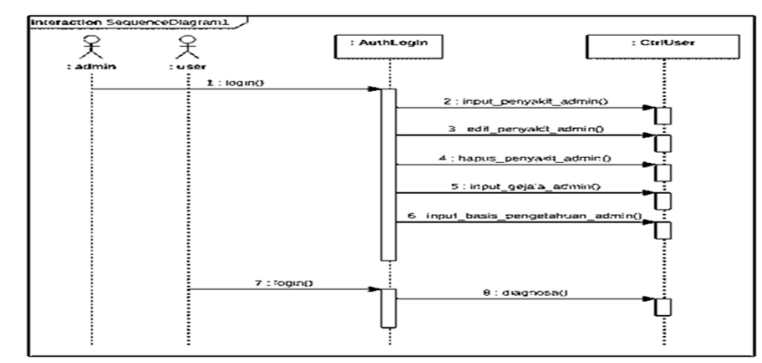

Fig. 5. Activity Diagram

In the description above, the admin and user first log in, then the admin can enter the disease, edit the disease, delete the disease, input symptoms and input the knowledge base. then the user must log in first to diagnose the disease. 


\section{A SEQUENCE DIAGRAM ANALYSIS OF BIG RED CHILI DISEASE}

Table 1. Disease analysis

\begin{tabular}{ll}
\hline Code & \multicolumn{1}{c}{ Disease } \\
\hline P001 & rot leaves (phytophthora) \\
P002 & leaf spot (Cercospora) \\
P003 & antraknosa fruit rot \\
P004 & powdery mildew (powdery mildew) \\
P005 & wilting bacteria (Pseudomonas) \\
P006 & fusarium wilt (Fusarium oxysporum) \\
P007 & sprout fall down \\
P008 & Complex virus \\
P009 & Gemini yellow virus \\
P010 & Swollen root nematodes \\
\hline
\end{tabular}

\section{B BIG RED CHILDREN SYMPTOMS ANALYSIS}

Table 2. Analysis of symptoms

\begin{tabular}{|c|c|}
\hline Kode & The symptoms \\
\hline G001 & $\begin{array}{l}\text { The wet spot is spotted on the edge or center } \\
\text { of the leaf }\end{array}$ \\
\hline G002 & $\begin{array}{l}\text { The patches are surrounded by white } \\
\text { sporangium }\end{array}$ \\
\hline G003 & leaves look rotten / lonyot like scalded \\
\hline G004 & young stems look rotten like scalded \\
\hline G005 & the whole leaf withers \\
\hline G006 & rot stems become dry and harden \\
\hline G007 & small patches of dark gray \\
\hline G008 & pale to white patches with older edges \\
\hline G009 & The leaves turn yellow and eventually fall \\
\hline G010 & Leaf spot measuring $0.25 \mathrm{~cm}$ \\
\hline G011 & Tears often occur at the center of the leaf \\
\hline G012 & $\begin{array}{l}\text { blackish brown spots on the surface of the } \\
\text { fruit, then the spots become soft }\end{array}$ \\
\hline G013 & $\begin{array}{l}\text { Dried leaves, twigs and branches are dark } \\
\text { brown }\end{array}$ \\
\hline G014 & $\begin{array}{l}\text { In the fungus acervuli stems seen in the form } \\
\text { of a lump }\end{array}$ \\
\hline G015 & Shoot off \\
\hline G016 & $\begin{array}{l}\text { on the underside of the old leaves there is a } \\
\text { layer of white flour }\end{array}$ \\
\hline G017 & The starched leaves turn yellow to form patches \\
\hline G018 & the leaves turn pale and fall out quickly \\
\hline G019 & plants that suddenly wither \\
\hline G020 & $\begin{array}{l}\text { The wilting plant starts from the shoot spread to } \\
\text { the bottom of the plant until all the leaves } \\
\text { wither and eventually the plant dies }\end{array}$ \\
\hline G021 & $\begin{array}{l}\text { the plants wither, starting from the lower } \\
\text { leaves }\end{array}$ \\
\hline G022 & yellowing leaf bone children \\
\hline G023 & stem and root tissue is brown \\
\hline
\end{tabular}




\begin{tabular}{|c|c|}
\hline Kode & The symptoms \\
\hline G024 & There are yellow spots on the buds \\
\hline G025 & The stems of plants are yellow \\
\hline G026 & $\begin{array}{l}\text { a brown wound at the base of the stem, so that } \\
\text { the stem is broken and eventually die }\end{array}$ \\
\hline G027 & the brown color at the base of the roots and rot \\
\hline G028 & $\begin{array}{l}\text { Young leaves have mosaic features that have } \\
\text { several features }\end{array}$ \\
\hline G029 & $\begin{array}{l}\text { Parts of chlorosis leaves can be light green to } \\
\text { yellow, even close to white }\end{array}$ \\
\hline G030 & $\begin{array}{l}\text { Often the leaf surface becomes uneven or } \\
\text { appears to have dark green curves }\end{array}$ \\
\hline G031 & Smaller leaf size \\
\hline G032 & Dappled leaf color green and light green \\
\hline G033 & $\begin{array}{l}\text { shoots in the form of yellow spots around the } \\
\text { leaf bone }\end{array}$ \\
\hline G034 & Yellow veins \\
\hline G035 & $\begin{array}{l}\text { Concave and contract with light or yellow } \\
\text { mosaic }\end{array}$ \\
\hline G036 & Concave leaves and contracted \\
\hline G037 & Leaf curl up \\
\hline G038 & There are yellow spots on the buds \\
\hline G039 & $\begin{array}{l}\text { on the roots of the lumps formed irregularly } \\
\text { formed }\end{array}$ \\
\hline G040 & In the case there are lumps like pimples \\
\hline
\end{tabular}

\section{BAYES THEOREM CALCULATION}

The following is a weighting table of the probability of disease and symptoms obtained from 3 experts related to the disease of large red chili plants. The value of the probability of the disease and symptoms will be a reference in the calculation of the Bayes Theorem method.

Table 3. Data Analysis of $\mathrm{P}(\mathrm{H})$ disease

\begin{tabular}{cc}
\hline \multicolumn{2}{c}{ Disease Weight } \\
Disease Code & $\begin{array}{c}\text { Weight P } \\
(\mathrm{H})\end{array}$ \\
\hline P001 & 0.5 \\
P002 & 0.4 \\
P003 & 0.8 \\
P004 & 0.4 \\
P005 & 0.3 \\
P006 & 0.3 \\
P007 & 0.3 \\
P008 & 0.3 \\
P009 & 0.7 \\
P010 & 0.2 \\
\hline
\end{tabular}


Table 4. Data Analysis of $\mathrm{P}(\mathrm{E} \mid \mathrm{H})$ symptoms

\begin{tabular}{|c|c|c|}
\hline \multicolumn{3}{|c|}{ Symptom Weight } \\
\hline $\begin{array}{l}\text { Symptom } \\
\text { Code }\end{array}$ & $\begin{array}{c}\text { Weight P (E } \mid \\
\mathrm{H})\end{array}$ & Disease Code \\
\hline G001 & 0.6 & P001 \\
\hline G002 & 0.7 & P001 \\
\hline G003 & 0.7 & P001 \\
\hline G004 & 0.9 & P001 \\
\hline G005 & 0.6 & P001 \\
\hline G006 & 0.7 & P001 \\
\hline G007 & 0.8 & P002 \\
\hline G008 & 0.7 & P002 \\
\hline G009 & 0.7 & P002 \\
\hline G010 & 0.6 & P002 \\
\hline G011 & 0.6 & P002 \\
\hline G012 & 0.7 & P003 \\
\hline G013 & 0.7 & P003 \\
\hline G014 & 0.6 & P003 \\
\hline G015 & 0.9 & P003 \\
\hline G016 & 0.8 & P004 \\
\hline G017 & 0.8 & P004 \\
\hline G018 & 0.7 & P004 \\
\hline G019 & 0.6 & P005 \\
\hline G020 & 0.6 & P006 \\
\hline G021 & 0.7 & P006 \\
\hline G022 & 0.6 & P006 \\
\hline G023 & 0.9 & P006 \\
\hline G024 & 0.7 & P006 \\
\hline G025 & 0.8 & P006 \\
\hline G026 & 0.6 & P007 \\
\hline G027 & 0.8 & P007 \\
\hline G028 & 0.7 & P008 \\
\hline G029 & 0.7 & P008 \\
\hline G030 & 0.7 & P008 \\
\hline G031 & 0.6 & P008 \\
\hline G032 & 0.6 & P008 \\
\hline G033 & 0.6 & P009 \\
\hline G034 & 0.6 & P009 \\
\hline G035 & 0.7 & P009 \\
\hline G036 & 0.9 & P009 \\
\hline G037 & 0.9 & P009 \\
\hline G038 & 0.8 & P009 \\
\hline G039 & 0.7 & P010 \\
\hline G040 & 0.6 & P010 \\
\hline
\end{tabular}

In the table above shows a data on disease analysis $\mathrm{P}(\mathrm{H})$ and symptoms $\mathrm{P}(\mathrm{E} \mid \mathrm{H})$, in the disease analysis table $\mathrm{P}(\mathrm{H})$ and the symptoms $\mathrm{P}(\mathrm{E} \mid \mathrm{H})$ have a probability value where the value probability is obtained from experts. The usefulness of the probability value is to find out ho w severe / often large red chili plants are affected by the disease. As well as with the probability value we can calculate the percentage value of the probability of the disease.

Calculation step: 
If chili plants experience 1 symptom then the calculation uses a formula, namely:, for example chili plants experience G001, G002, G009 the value of these symptoms can be seen in tables 3.3 and 3.4 , namely $0.6,0.7$ and 0.7 . diseases that have these symptoms are only in $\mathrm{C} 3$ and $\mathrm{C} 4$. The following statement of symptoms and disease along with the code, namely: (G001) Wet-wet spots on the edge or middle of the leaf, (G002) Leaves look decaying / loyot like scalded, (G009) Leaves turn yellow and eventually fall off and (P001) rot leaf, (P002) leaf spot.

From the statement of symptoms and diseases above, we first do a manual calculation in table 3.5, namely by entering the disease code, the symptom code, the weight value of $\mathrm{P}(\mathrm{H})$, the Symptoms of $\mathrm{P}(\mathrm{E} \mid \mathrm{H})$ as below, namely:

Table 5. Manual calculation

\begin{tabular}{lcccc}
\hline $\mathrm{X}$ & $\begin{array}{c}\text { Code } \\
\text { the } \\
\text { symptoms }\end{array}$ & $\begin{array}{c}\text { Disease } \\
\text { code }\end{array}$ & $\begin{array}{c}\mathrm{P}(\mathrm{H}) \\
\text { disease }\end{array}$ & $\begin{array}{c}\mathrm{P}(\mathrm{E} \mid \mathrm{H}) \\
\text { symptoms }\end{array}$ \\
\hline $\begin{array}{l}\text { Enter the } \\
\text { symptom } \\
\text { code 1 }\end{array}$ & G001 & $\mathrm{P} 001$ & 0.5 & 0.6 \\
$\begin{array}{l}\text { Enter the } \\
\text { symptom } \\
\text { code 2 }\end{array}$ & G003 & P001 & 0.5 & 0.7 \\
$\begin{array}{l}\text { Enter } \\
\text { symptom } \\
\text { code 3 }\end{array}$ & G009 & P002 & 0.4 & 0.7 \\
\hline
\end{tabular}

Next after doing manual calculation, first we calculate the probability value by comparing the disease code P001 in the calculation table with the disease code P001 in the table of disease weights. Then if the disease code P001 is the same then to look for probabilities of P001 look at Symptom-1 by multiplying the weight value of $\mathrm{P}(\mathrm{H})$ with the Symptom $\mathrm{P}(\mathrm{E} \mid \mathrm{H})$ as below: "P (H). P $(\mathrm{E} \mid \mathrm{H})$ "/" P (H). P $(\mathrm{E} \mid \mathrm{H}) "=(0.5$. 0.6) / (0.5. 0.6) $=0.3 / 0.3=1$, then if the disease code P001 and G002 in the calculation table is manul and the table is in the weight of the disease is not the same then given a value of 0, and the disease code P003 and G009 in the calculation table manul and the table in the weight of the disease is not the same then given a value 0 . So on like that until you know the probability value P002 looks at symptoms 2 and the probability of P003 looking at symptom 3.

Table 6. Probability Calculation

\begin{tabular}{lccc}
\hline X & Probability P001 & Probability P002 & Probability P003 \\
\hline The symptoms & 1 & 0 & 0 \\
The symptoms 3 & 1 & 0 & 0 \\
The symptoms & 0 & 1 & 0 \\
Total & 2 & 1 & 0 \\
Probability & 0.666666667 & 0.333333333 & 0 \\
percentage & $67 \%$ & $33 \%$ & $0 \%$ \\
\hline
\end{tabular}

Furthermore, after we know the results of the probability of P001 looking at the symptom1 is 1 , the probability of P002 looking at the symptom 2 is 0 and the probability of P003 looking at the Symptom-1 is 0 , then we calculate the total by adding the probability value P001 is 2 and many diseases encountered are 3 so 2 divided by 3 is 0.666666667 , the probability of P002 is 1 divided by 3 is 0.333333333 , P002, the probability of P003 is 0 . 
Lastly, we calculate the percentage of disease, namely by the results of the overall probability multiplied by 100 which is 0.666666667 multiplied by 100 is $67 \%, 0.333333333$ multiplied by 100 is $33 \%$ and 0 multiplied by 3 is 0 .

\section{E Interface Implementation}

a. Login Page Interface

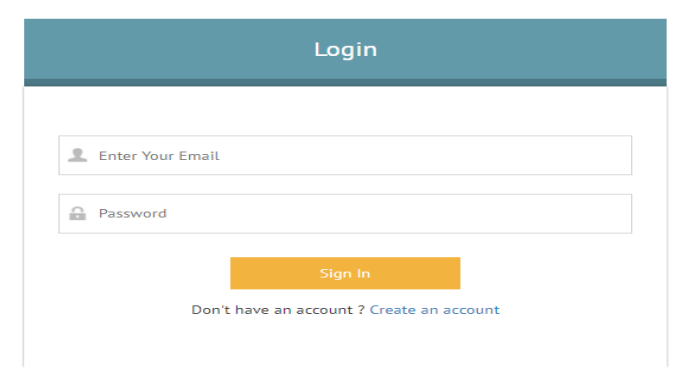

Fig 6. Login Page Interface

Figure illustrates the implementation of the login page login interface where the admin and user can fill in an email and password to enter the admin page on the expert system application to diagnose the disease of large red chili plants.

b. Implementation of Interface Pages Managing Configuring Data

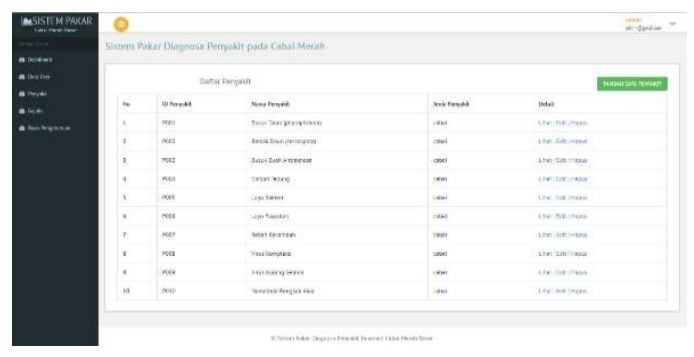

Fig. 7. Interface Pages Managing Disease Data

Figure 7 describes the interface page for managing disease data in the expert system for diagnosing large red pepper plants, this page can only be accessed by the admin. 
c. Implementation of Interface Pages Manage Data Symptoms

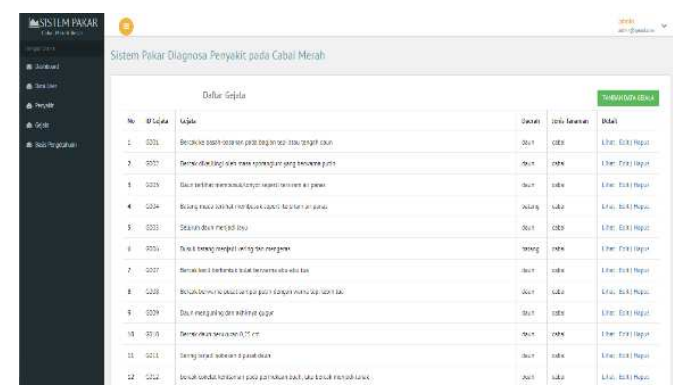

Fig. 8. Implementation of Interface Pages Manage Data Symptoms

Figure 8 describes the interface page managing symptom data in the expert system of diagnosing large red pepper plants, this page can only be accessed by the admin.

d. Implementation of Knowledge Base Interfaces

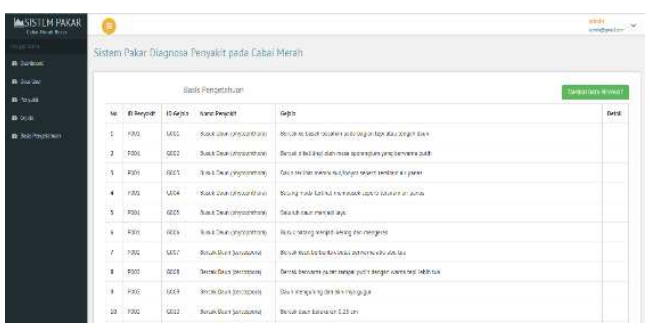

Fig. 9. Knowledge Base Interface

explain the knowledge base page interface in the expert system for diagnosing large red chili plants, this page can only be accessed by the admin.

e. Implementation of Disease Diagnosis Page Interface
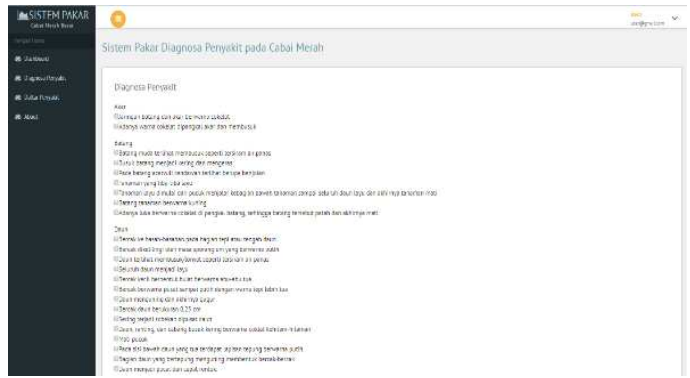

Fig. 10. Disease Diagnosis Page 
explain the interface of the disease diagnosis page in the expert system for diagnosing large red pepper plants, this page can only be accessed by the user.

\section{f. Testing}

System accuracy testing is done to test how well the diagnosis of the possibility of a large red chili disease is made in the application. The following are the results of the accuracy testing of the expert system for diagnosing large red chili plants:

Table 7. Accuracy Testing

\begin{tabular}{|c|c|c|c|c|c|}
\hline No & Symptom Code & $\begin{array}{c}\text { Expert } \\
\text { Application of } \\
\text { large red chili } \\
\text { plants } \\
\end{array}$ & $\begin{array}{c}\text { Expert } \\
\text { Ir Tonny Koestoni } \\
\text { Moekasan }\end{array}$ & $\begin{array}{c}\text { Expert } \\
\text { Yusuf Hidayat, SP, } \\
\text { Mphil }\end{array}$ & $\begin{array}{c}\text { Expert } \\
\text { Dr. Sri Hartati, SP., } \\
\text { M.SI }\end{array}$ \\
\hline 1. & G001,G003,G009 & $\begin{array}{c}\text { rot leaves } \\
66,67 \%\end{array}$ & rot leaves $66,67 \%$ & rot leaves $66,67 \%$ & rot leaves $66,67 \%$ \\
\hline 2. & G012,G013,G014 & $\begin{array}{l}\text { antraknosa fruit } \\
\text { rot } 100 \%\end{array}$ & $\begin{array}{c}\text { antraknosa fruit rot } \\
100 \%\end{array}$ & $\begin{array}{c}\text { antraknosa fruit rot } \\
100 \%\end{array}$ & $\begin{array}{c}\text { antraknosa fruit rot } \\
100 \%\end{array}$ \\
\hline 3. & $\begin{array}{c}\text { G007,G008,G009, } \\
\text { G010 }\end{array}$ & $\begin{array}{c}\text { rot leaves } \\
100 \%\end{array}$ & rot leaves $100 \%$ & rot leaves $100 \%$ & rot leaves $100 \%$ \\
\hline 4. & G016,G017,G018 & $\begin{array}{c}\text { Dew Flour } \\
100 \%\end{array}$ & Dew Flour $100 \%$ & Dew Flour $100 \%$ & Dew Flour $100 \%$ \\
\hline 5. & $\begin{array}{l}\text { G019,G020,G021, } \\
\text { G022 }\end{array}$ & $\begin{array}{c}\text { Fusarium wilt } \\
75 \%\end{array}$ & $\begin{array}{c}\text { Fusarium wilt } \\
75 \%\end{array}$ & $\begin{array}{l}\text { Fusarium wilt } \\
75 \%\end{array}$ & $\begin{array}{c}\text { Fusarium wilt } \\
75 \%\end{array}$ \\
\hline 6. & G026, G025,G040, & $\begin{array}{c}\text { Sprout Sprout } \\
33,33 \%\end{array}$ & $\begin{array}{c}\text { Sprout Sprout } \\
33,33 \%\end{array}$ & $\begin{array}{c}\text { Sprout Sprout } \\
33,33 \%\end{array}$ & $\begin{array}{c}\text { Sprout Sprout } \\
33,33 \%\end{array}$ \\
\hline 7. & $\begin{array}{c}\text { G033,G034,G040 } \\
\text { G012 }\end{array}$ & $\begin{array}{c}\text { Gemini Yellow } \\
\text { Virus } 50 \%\end{array}$ & $\begin{array}{c}\text { Gemini Yellow } \\
\text { Virus } 50 \%\end{array}$ & $\begin{array}{c}\text { Gemini Yellow Virus } \\
50 \%\end{array}$ & $\begin{array}{c}\text { Gemini Yellow } \\
\text { Virus } 50 \%\end{array}$ \\
\hline 8. & $\begin{array}{c}\text { G007,G010,G005, } \\
\text { G013 }\end{array}$ & Leaf spot $50 \%$ & Leaf spot $50 \%$ & Leaf spot $50 \%$ & Leaf spot $50 \%$ \\
\hline 9. & G010,G018,G039 & $\begin{array}{c}\text { Dew Flour } \\
33,335\end{array}$ & $\begin{array}{c}\text { Dew Flour } \\
33,335\end{array}$ & $\begin{array}{c}\text { Dew Flour } \\
33,335\end{array}$ & $\begin{array}{c}\text { Dew Flour } \\
33,335\end{array}$ \\
\hline 10. & G027 & $\begin{array}{c}\text { Sprout sprouts } \\
100 \%\end{array}$ & $\begin{array}{c}\text { Sprout sprouts } \\
100 \%\end{array}$ & Sprout sprouts $100 \%$ & $\begin{array}{c}\text { Sprout sprouts } \\
100 \%\end{array}$ \\
\hline 11 & G039,G040 & $\begin{array}{l}\text { Swollen root } \\
\text { nematodes } \\
100 \%\end{array}$ & $\begin{array}{c}\text { Swollen root } \\
\text { nematodes } 100 \%\end{array}$ & $\begin{array}{c}\text { Swollen root } \\
\text { nematodes } 100 \%\end{array}$ & $\begin{array}{c}\text { Swollen root } \\
\text { nematodes } 100 \%\end{array}$ \\
\hline 12. & G013,G015,G020 & $\begin{array}{c}\text { Anthracnose } \\
\text { Fruit Rot } \\
66,67 \%\end{array}$ & $\begin{array}{c}\text { Anthracnose Fruit } \\
\text { Rot } 66,67 \%\end{array}$ & $\begin{array}{c}\text { Anthracnose Fruit Rot } \\
66,67 \%\end{array}$ & $\begin{array}{c}\text { Anthracnose Fruit } \\
\text { Rot } 66,67 \%\end{array}$ \\
\hline 13. & $\begin{array}{c}\text { G024,G028,G029, } \\
\text { G033 }\end{array}$ & $\begin{array}{c}\text { Complex Virus } \\
50 \%\end{array}$ & $\begin{array}{c}\text { Complex Virus } \\
50 \%\end{array}$ & Complex Virus $50 \%$ & Complex Virus $50 \%$ \\
\hline 14. & $\begin{array}{c}\text { G002,G022,G026, } \\
\text { G030 }\end{array}$ & $\begin{array}{c}\text { Sprout Sprout } \\
25 \%\end{array}$ & Sprout Sprout 25\% & Sprout Sprout 25\% & Sprout Sprout 25\% \\
\hline $\begin{array}{l}15 . \\
16 .\end{array}$ & $\begin{array}{c}\text { G010,G037 } \\
\text { G028,G029,G030 }\end{array}$ & $\begin{array}{l}\text { Leaf spot } 50 \% \\
\text { Complex Virus }\end{array}$ & $\begin{array}{c}\text { Leaf spot } 25 \% \\
\text { Complex Virus } \\
100 \%\end{array}$ & $\begin{array}{c}\text { Leaf spot } 25 \% \\
\text { Complex Virus } 100 \%\end{array}$ & $\begin{array}{c}\text { Leaf spot } 25 \% \\
\text { Complex Virus } \\
100 \%\end{array}$ \\
\hline 17. & G032,G033,G035 & $\begin{array}{l}\text { Gemini Yellow } \\
\text { Virus } 66,67 \%\end{array}$ & $\begin{array}{l}\text { Gemini Yellow } \\
\text { Virus } 66,67 \%\end{array}$ & $\begin{array}{c}\text { Gemini Yellow Virus } \\
66,67 \%\end{array}$ & $\begin{array}{c}\text { Gemini Yellow Virus } \\
66,67 \%\end{array}$ \\
\hline
\end{tabular}


To find out the results in the case of experimental accuracy of the expert system for diagnosing large red chili plants, it is calculated as follows:

$$
\text { Accuracy Value }=\frac{\text { Appropriate amount }}{\text { Number of cases }} \times 100 \%
$$

Accuracy Value of Large Red Chili Plant Disease Diagnosis Results $=\frac{100}{100} \times 100 \%=100 \%$

Based on tests conducted on 100 test data the results of the accuracy of the expert system for diagnosing the disease of large red chili plants is $100 \%$.

\section{Conclusion}

The expert system for diagnosing large red chili plants is a system that provides information on possible diseases in large red chili plants in expert systems by inputting symptoms experienced by the user. The system can provide a percentage of the probability of illness through calculations in the expert system of large red chili plants after inputting the symptoms experienced by the user. Therefore, this study entitled the application of the Bayes theorem to an expert system for diagnosing large red-based red chili plant diseases. The Bayes theorem is a method used to know the calculation of the probability value of the identification of a large red chili disease.

Based on the results of experimental data on the symptoms of large red chili disease, the accuracy value was $100 \%$. This expert system is declared valid, and can function properly with expert diagnostic processes on Bayes theorem manual calculations.

\section{References}

[1] S. Pitojo, Benih Cabai. Yogyakarta: kanisius, 2003.

[2] H. Semangun, Penyakit-penyakit tanaman holtikultura di indonesia (edisi kedua). Yogyakarta: Gadjah Mana University Press, 2007.

[3] Badan Pusat Statistik Lampung, Berita Resmi Statistik Provinsi Lampung. Lampung: Badan Pusat Statistik Provinsi Lampung, 2014.

[4] P. Cabai merah: "komoditas prospektif dan andalan", balai penelitian tanaman sayuran pusat penelitian dan pengembangan holtikultura, Badan Penelitian dan pengembangan Pertanian, Duriat A.S. 1996.

[5] H. Semangun, Penyakit-penyakit tanaman holtikultura di indonesia Gajah Mada University Press. Yogyakarta, 2004.

[6] M.B.A,Riduan, Dasar-dasar Statistik. bandung: ALFABETA, 2006.

[7] and D. V. S. T. Sutojo, E.Mulyanto, Kecerdasan Buatan. jakarta: Andi, 2011.

[8] M.Arhami, Kecerdasan Buatan. 2005.

[9] B. Sidik, Pemrograman web dengan PHP, Edisi Revisi. bandung: INORMATIKA BANDUNG, 2012.

[10] R. S. Presman, Rekayasa perangkat lunak (Pendekatan Praktisi) Edisi 7. Yogyakarta: Andi, 2012. 